\title{
The Physical Condition of Red Deer Falling a Prey to the Wolf and Lynx and Harvested in the Carpathian Mountains ${ }^{{ }^{1}}$
}

\author{
Henryk OKARMA
}

\begin{abstract}
Okarma H., 1983: The physical condition of red deer falling a prey to the wolf and lynx and harvested in the Carpathian Mountains. Acta theriol., 29, 23: 283-290 [With 2 Tables \& 2 Figs.]

Examination was made of the condition of red deer killed by wolves and lynxes in the Bieszczady Mountains over a period of two winters $(1981 / 82$ and $1982 / 83)$ or shot by hunters. The fat content in the bone marrow of the limbs was taken as a criterion of condition. Important differences were found in the age structure of red deer killed by wolves and lynxes. All the animals killed by the latter were fawns had been bitten to death in February and March, whereas they formed $29 \%$ of the wolf's diet in December and January, and $49 \%$ in February and March. The average age of adult animals killed by wolves in those two parts of the winter season was similar and was respectively 4.8 and 4.4 years. Hinds formed $61 \%$ of the adults killed, the remainder, $39 \%$, being stags. The studies showed that the condition of animals killed by wolves and lynxes differed greatly. As many as $82 \%$ of the fawns killed by lynxes were weak animals with up to $20 \%$ of fat in the femoral bone marrow, whereas they formed only 33\% of the wolf's diet, while physically strong fawns with fat content of $80-100 \%$ formed the same percentage.

[Department of Animal Ecology, Jagiellonian University, Karasia 6, 30-060 Kraków, Poland].
\end{abstract}

\section{INTRODUCTION}

The wolf (Canis lupus Linnaeus, 1758) and lynx (Lynx lynx Linnaeus, 1758 ) occur in Poland over an area of about $25,000 \mathrm{~km}^{2}$, but settled populations of these species live chiefly in the north-eastern and southeastern regions of Poland (Sumiński, 1974). Heated discussions on the subject of the wolf's role as natural selector recur after each severe winter, when traces of its feeding, particularly among populations of red deer inhabiting the Carpathian area, are both numerous and spectacular.

Ungulate mammals accumulate a large amount of reserve fat during the growing season (Harris, 1945; Cheatum, 1949; Riney, 1955). During the first phase of their winter utilization it is the reserves of subcutaneous fat which are first used up, then the fat in the abdominal cavity and bone marrow of the limbs. The fat of bone marrow in the limbs is used in turn from the femur and humerus, then the tibia and radius, then from the metatarsal and metacarpal bones (Brooks et al., 1977; Ratcliffe, 1980; Reich, 1981).

${ }^{1}$ Praca wykonana w ramach problemu międzyresortowego MR.II.19 koordynowanego przez SGGW-AR.

[283] 
An attempt has been made in the present paper at defining, on the basis of the above physiological mechanisms, the condition of red deer either killed by wolves or lynxes, or shot by hunters.

\section{STUDY AREA, MATERIAL AND METHODS}

The studies were carried out during the winter seasons $1981 / 82$ and 1982/83 in the Bieszczady Mountains (south-eastern Poland) in the forest administration districts of Komańcza, Cisna and Baligród. This area is sparsely populated and inaccessible mountainous land (about 50,000 in area) from the central massif of Chryszczata rising to a height of $997 \mathrm{~m}$ above sea level. It is covered by mountain forests of the Fagetum-Carpaticum type, forming $97 \%$ of all the wooded land occurring in this particular region. Settled populations of wolves, lynxes and bears (Ursus arctos Linnaeus, 1758), live there, but their exact numbers are unknown. Ungulates are represented primarily by red deer (Cervus elaphus elaphus Linnaeus, 1758), which are estimated to number 1200 head within the area of these three forest administration districts (Kosobucka, 1981). Wild boar (Sus scrofa Linnaeus, 1758) also occur here, and sporadically roe deer, Capreolus capreolus (Linnaeus, 1758).

The material was collected during weekly inspections of the area from November to March. The kind of predator was defined from tracks and also the place and manner of killing the prey. The sex of prey was also established, and age from wear of teeth in the lower jaw. Prey up to 12 months was classified as fawns, and above this age limit as adult animals. The second part of the material consisted of red deer shot by hunters and 2 individuals which had died of starvation.

The bones of one hind leg were removed from carcasse. Marrow samples of 20-30 $\mathrm{g}$ were taken from the middle part of the femur, tibia and metatarsus $\left(\mathrm{Mt} s+\mathrm{Mt}_{4}\right)$. The weighed samples were placed in Petri dishes and ovendried at $60^{\circ} \mathrm{C}$ to constant weight and their dry weight expressed as a percentage of the initial wet weight. The first samples taken from 12 red deer were ether extracted. As the non-fat residue left after extraction formed $2-4 \%$ of the sample weight, the fat content in the bone marrow of the other individuals was defined by means of drying, assuming that it is equal to the percentage of the sample dry weight (Neiland, 1970).

During the course of the two study seasons marrow samples were taken from 34 animals killed by the wolf, 11 by the lynx, 7 shot by hunters and from a young stag and old hind which had both died of starvation.

\section{RESULTS}

Differences were found in the age structure of red deer killed by wolves or lynxes. All those killed by the latter were young animals (fawns) killed in February and March. These individuals formed 29\% of the wolf's diet during the early winter (December, January) and $49 \%$ in February and March (Fig. 1). The remainder of the animals killed by wolves were adult red deer, the average age of which in the two parts of the winter season compared did not greatly differ and were 4.8 and 4.4 years. It was found that $61 \%$ of adult animals killed by wolves ( 11 animals) were hinds, and the remainder ( 7 animals) stags. 
Progressive utilization of bone marrow fat in the legs, beginning with the proximal and continuing to the distal bones, was found in the animals examined. The amount of fat was lowest in the femur, intermediate in the tibia and greatest in the metatarsus (Table 1,2). During the winter the content of this component of the marrow decreased, although retaining the above trend, and its decrease was most abrupt in young animals (Table 1,2). No great difference was found in the condition of fawns from late winter, killed by wolves or shot by hunters (Table 1), whereas young animals killed by lynxes had nearly two and a half ti-

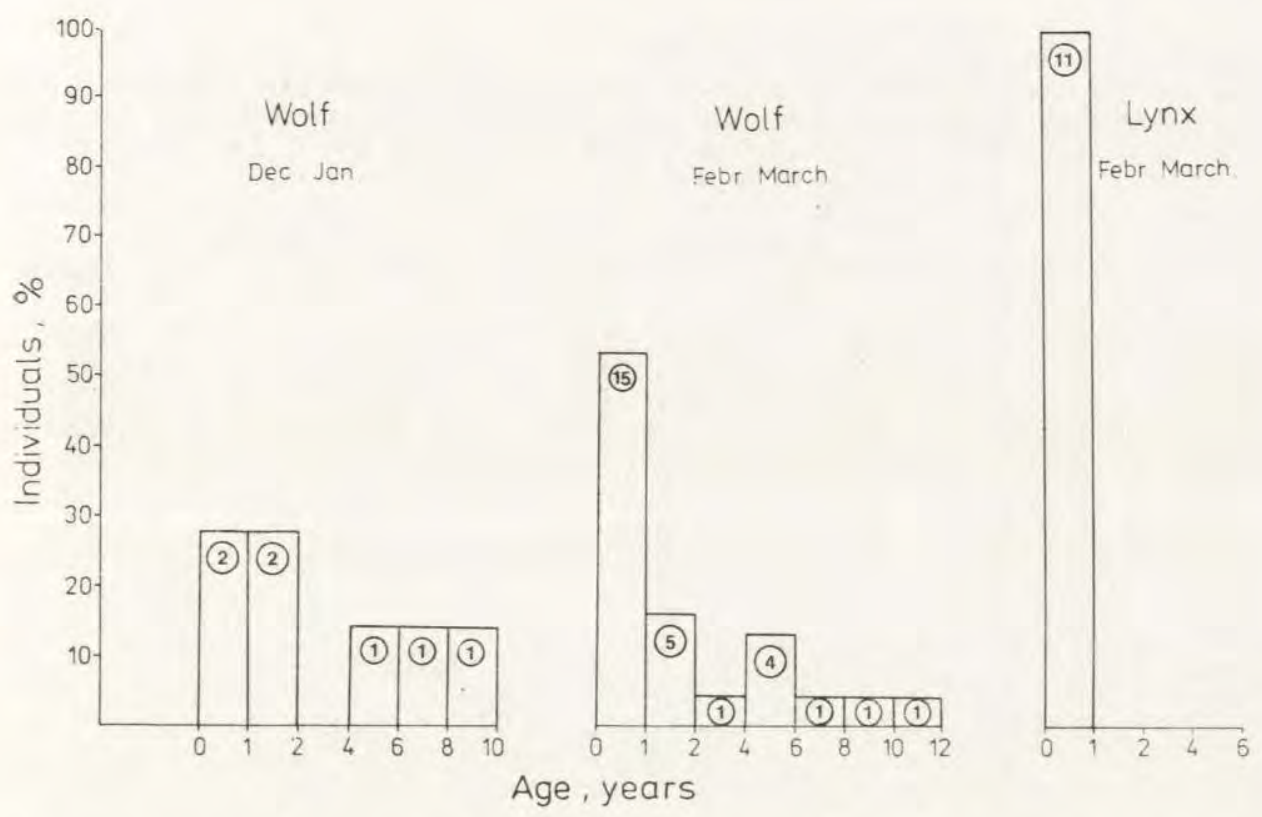

Fig. 1. Age structure of red deer killed by wolves and lynxes in the area of the Komańcza, Cisna and Baligród forest administration districts. The number of animals examined is given inside circles.

mes lower fat content in the marrow of the femur. In fawns which formed the prey of predators in February and March differences between those killed by wolves and lynxes were statistically significant $(t=2.37$; $p=0.05$ ). Animals killed by wolves in December and January had a slightly lower percentage of fat in the bone marrow than red deer shot by hunters during the same period. In the second half of the winter season this difference was considerable. Hence the differences in the fat contents of bone marrow were determined between means, the procedure do not illustrate the actual range of physical condition in animals killed by predators neither do they reflect the characteristics of feeding by the wolf and lyx. In order better to illustrate this pheno- 


\section{Table 1}

Fat content $(\%)$ in the bone marrow of hind legs in red deer fawns killed by wolves, lynxes, or shot in the Komańcza, Cisna and Baligród forest administration districts. Arithmetical means and standard deviation values are given. The number of animals examined is given in brackets.

\begin{tabular}{|c|c|c|c|c|}
\hline Bone & $\begin{array}{r}\text { Wolf } \\
\text { Dec., Jan. }(n=2)\end{array}$ & $\begin{array}{l}(\mathrm{n}=17) \\
\text { Febr., March }(\mathrm{n}=15)\end{array}$ & $\begin{array}{l}\text { Lynx }(n=11) \\
\text { Febr., March }\end{array}$ & $\begin{array}{l}\text { Shot }(\mathrm{n}=2) \\
\text { Febr., March }\end{array}$ \\
\hline Femur & $92.3 \pm 2.3$ & $46.6 \pm 34.4$ & $18.7 \pm 21.3$ & $45.7 \pm 29.4$ \\
\hline Tibia & $93.1 \pm 0.6$ & $49.8 \pm 34.2$ & $21.1 \pm 23.8$ & $49.5 \pm 23.5$ \\
\hline Metatarsus & $93.7 \pm 1.8$ & $58.7 \pm 29.6$ & $31.0 \pm 22.3$ & $52.5 \pm 22.6$ \\
\hline
\end{tabular}

Table 2

Fat content $(\%)$ in the bone marrow of hind legs of adult red deer killed by wolves or shot in the Komańcza, Cisna and Baligród forest administration districts. Arithmetical means and standard deviation values are given. The number of animals examined is given in brackets.

\begin{tabular}{lcccc}
\hline \multirow{1}{*}{ Bone } & \multicolumn{2}{c}{ Wolf $(\mathrm{n}=18)$} & \multicolumn{2}{c}{ Shot $(\mathrm{n}=5)$} \\
& Dec., Jan., & Febr., March, & Dec., Jan., & Febr., March, \\
& $n=5$ & $n=13$ & $\mathrm{n}=3$ & $\mathrm{n}=2$ \\
Femur & $88.0 \pm 3.9$ & $69.9 \pm 22.9$ & $92.9 \pm 2.0$ & $91.4 \pm 2.8$ \\
Tibia & $93.1 \pm 0.6$ & $74.2 \pm 21.4$ & $94.8 \pm 2.4$ & $94.0 \pm 6.1$ \\
Metatarsus & $92.3 \pm 2.8$ & $86.1 \pm 6.4$ & $95.2 \pm 1.9$ & $95.1 \pm 5.1$ \\
\hline
\end{tabular}

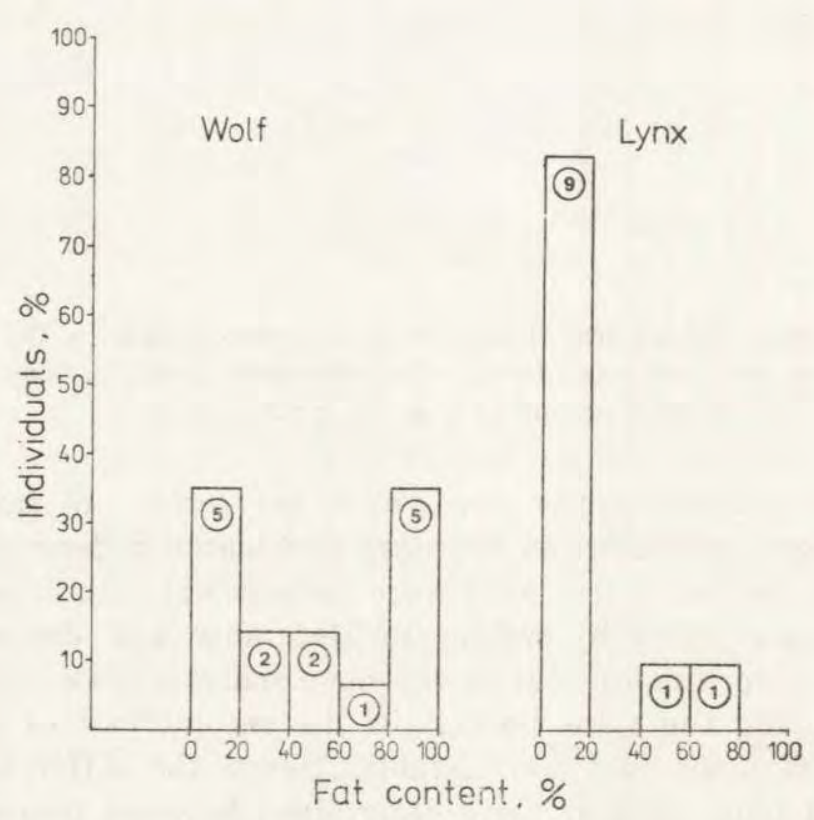

Fig. 2. Percentage distribution of fawns killed by predators in different intervals of fat content in the femoral bone marrow. The number of animals examined is given inside circles. 
menon a histogram has been drawn up of the percentages formed by prey in different intervals of fat content in femoral bone marrow (Fig. 2). As many as $82 \%$ of fawns killed by lynxes are animals in exceptionally poor condition, in which marrow fat content does not exceed $20 \%$. The physical condition structure of young red deer killed by wolves is completely different, only $33 \%$ of the fawns being weak individuals in which fat content does not exceed $20 \%$. At the same time a similar percentage is formed by physically strong individuals with up to $80-100 \%$ fat in the femoral bone marrow (Fig. 2).

Fat content in the red deer which had died of starvation was far lower than in the prey of wolves and lynxes, being on an average $9 \%$ in the femur, $12 \%$ in the tibia and $30 \%$ in the metatarsus.

\section{DISCUSSION}

When measuring fat content in bone marrow of the legs it is only the relative condition of the animal concerned which is determined, since it is impossible to determine simultaneously the amount of subcutaneous and mesenteric fat, and the fat index of the kidneys. When inspecting animals killed by predators it is seldom that there is any possibility of fully estimating their condition, as the soft tissues are the first to be eaten and are only exceptionally available for analysis.

The results of analyses of bone marrow in red deer killed by predators or shot showed that lynxes most effectively select prey from the physical aspect. The size of the lynx's body limit the circle of its potential victims to weak or very young animals. The condition of red deer deteriorates considerably during winter and it is the young animals which are most unfavourably affected by difficult terrain and weather conditions (Bergerud, 1971).

The structure of condition in the prey of the wolf may give rise to considerable controversy, since its diet has been found also to contain physically strong animals, even during the period when the general condition of red deer populations is poorer (late winter). Similar results were obtained by Canadian research workers. Kolenosky (1972) found that Virginian deer Odocoileus virginianus (Zimmermann, 1780) killed by wolves were in good condition; Carbin (1980) states that fat content in femoral bone marrow in red deer Cervus elaphus nelsoni Nelson, 1902 killed by wolves was high, with an average figure of $80 \%$.

Several interpretations of the fact that wolves also kill red deer in good condition are possible:

1. The wolf in hunting does not act selectively, on account of the large number of potential prey and the severe winter conditions prevailing in the study area. With deep snow cover and thin ice surface layer red deer sink in deeply, while the wolf, being lighter, moves with far great agility and easily catches up with its prey. In such cases selection does 
not take place, only almost random encounters between the predator and prey, since the intrapopulation differences in condition are very strongly evened up by climatic conditions. Under these circumstances both strong and weak animals have similar chances of escaping. Mech (1966), however, stated that such specific conditions occur comparatively seldom and are not therefore of great importance.

2. The paper presented here does not give a general picture of the physical condition of an individual as the red deer, having a high fat content in bone marrow, may have its remaining energy reserves completely exhausted. Other factors, such as disease, parasites and congenital abnormalities, leaving no traces in those parts of the victims body remaining after two wolves have left, cannot be ruled out (Mech, 1970).

3. Hypothesis of behavioural selection. The hunting technique of wolves differs from that of other predators in open spaces with good visibility, e.g. the Serengetti plain (Reich, 1981). They do not behave according to the pattern of "coursing predators" - that is, they do not chase their prey for long distances. With this way of hunting the weakest individuals are left behind the main group of escaping animals and fall victims to predators.

Wolves chase their prey over relatively short distances. In most of the sightings the distance did not exceed several hundred metres (Mech 1970; Mech \& Frenzel, 1971; Trokowicz, 1970). "In reality, the wolf's hunting technique is based on the sudden-rush tactic wherein stalking and a quick burst of speed, followed by a short chase, are the main factors in overcoming prey" (Mech, 1970).

In mountain areas wolves hunt both singly and in groups, in an organized way. Mountainous terrain with numerous streams, thickly wooded and with dense undergrowth, results in herds of red deer scattering round these obstacles. Such conditions also favour the wolf's stealthy approach to its prey. The distance at which the red deer notices the predator and distance of attack is sometimes not more than approximately 50-60 metres. The wolf does not attack a whole group but selects an animal on the side of it (author's unpubl. data). If the sudden attack is unsuccessful the wolf soon gives up the chase and searches the area for the next potential prey (Mech, 1970; Mech \& Frenzel, 1971). There can thus be no question of "testing" red deer from the condition aspect by long-lasting chase. By hunting in this way the predator may equally well kill strong animals or those physically weak, which have separated from the group and have not been sufficiently alert. Wolves also hunt in an organized fashion. One or several predators drive a selected animal in the direction of the other members of the pack (Trokowicz, 1980), and here again the criterion for choice of prey is its distance from the group (author's unpubl. data).

It would appear possible that under mountainous conditions and 
with a large number of potential prey, the criterion for selection becomes both the animal's condition and its behaviour. In line with this assumption the animals which for various reasons stray from herd will be eliminated first, and not remaining in relatively compact group. This type of selection may be defined by the term behavioural selection.

It would be necessary to carry out studies of predators' prey on a far greater scale and simultaneously supported by observations of the wolf's hunting technique under mountanous conditions, in order to obtain confirmation for this hypothesis.

Acknowledgements: The author should like to thank Mrs J. Sadura, J. Kamiński for their help in collecting material, and Doc. B. Bobek for this valued suggestions during the writing of this paper.

\section{REFERENCES}

1. Bergerud A. T., 1971: The population dynamics of Newfoundland caribou. Wildl. Monogr., 25: 1-55.

2. Brooks P. M., Hanks J. \& Ludbrook J. V., 1977: Bone marrow as an index of condition in African ungulates. S. Afr. J. Wildl. Res., 7: 61-66.

3. Carbyn L. N., 1980: Ecology and management of wolves in Riding Mountain National Park, Manitoba. Canadian Wildl. Serv., Edmonton: 1-184.

4. Cheatum E. L., 1949: Bone marrow as an index of malnutrition in deer. New York State Conserv., 3(5): 19-22.

5. Harris D., 1945: Symptoms of malnutrition in deer. J. Wildl. Manage., 9: $319-322$.

6. Hunt H. M., 1979: Comparison of dry-weight methods for estimating elk femur marrow fat. J. Wildl. Manage., 43: 560-562.

7. Kolenosky G. B., 1972; Wolf predation on wintering deer in east-central Ontario. J. Wildl. Manage., 34: 357-369.

8. Kosobucka M., 1981: [Population density and harvest rate of red deer (Cervus elaphus) in mountain forest ecosystems of southeastern Poland]. M. S. Thesis, Jagiellonian University, Cracow, Poland. [In Polish].

9. Mech L. D., 1966: The wolves of Isle Royale. Natl. Parks Fauna Ser., 7: $1-210$.

10. Mech L. D., 1970: The wolf. Nat. Hist. Press, Doubleday: 1-384. New York.

11. Mech L. D. \& Frenzel L. D., JR. (Eds.), 1971: Ecological studies of the timber wolf in northeastern Minnesota. USDA For. Serv. Res. Pap. NC-52: 1-59.

12. Neiland K. A., 1970: Weight of dried marrow as indicator fat in caribou femurs. J. Wildl. Manage., 34: 904-907.

13. Ratcliffe P. R., 1980: Bone marrow fat as an indicator of condition in roe deer. Acta theriol., 25: 333-340.

14. Reich A., 1981: Sequential mobilisation of marrow fat in the Impala (Aepyceros melanpus) and analysis of condition of Wild Dog (Lycaon pictus) prey. J. Zool., 194: 409-421.

15. Riney T., 1955: Evaluating condition of free-ranging red deer (Cervus elaphus) with special reference to New Zealand. New Zealand J. Sci. Tech., Sec. B, 36: $428-463$.

16. Sumiński P., 1974: The wolf in Poland. Proc. First Working Meeting of Wolf Specialist and of the First International Conference on the Conservation of the Wolf. Stockholm, 1973: 44-52. 
17. Trokowicz L., 1980: [On the wolf tract in the Biebrza river valley]. Przegl Zool. 24: 137-145. [In Polish].

Accepted, March 15, 1984.

\section{Henryk OKARMA}

\section{KONDYCJA FIZYCZNA JELENI PADAJĄCYCH OFIARA WILKOW I RYSI ORAZ POZYSKANYCH W KARPATACH}

\section{Streszczenie}

Na terenie Bieszczad w ciągu dwóch zim: 1981/82 i 1982/83 analizowano kondycję jeleni, które padły ofiarą wilków i rysi oraz zostały odstrzelone przez myśliwych. Jako wskaźnik kondycji przyjęto zawartość tłuszczu w szpiku kości kończyn.

Stwierdzono poważne różnice $w$ strukturze wiekowej jeleni zabitych przez wilki i rysie. Wszystkie ofiary rysia to cielaki zagryzione w lutym i marcu, natomiast w diecie wilka stanowily one $29 \%$ w czasie grudnia i stycznia, a $49 \%$ w lutym i marcu (Ryc. 1). Sredni wiek dorosłych zwierząt zabitych przez wilki w tych dwóch częściach sezonu zimowego był podobny i wynosil odpowiednio 4,8 i 4,4 lat. Eanie stanowiły $61 \%$ dorosłych ofiar, a resztę tj. $39 \%$ byki. $U$ badanych zwierząt wykazano progresywne wykorzystanie tluszczu szpikowego kończyn poczynając od kości proksymalnych do dystalnych (Tabele 1, 2).

Charakterystyka stanu fizycznego ofiar wilka i rysia znacznie się różni. Aż $82 \%$ cieląt zabitych przez rysia to osobniki slabe mające do $20 \%$ tluszczu w szpiku kości udowej. Natomiast dietę wilka formowały one tylko w $33 \%$, przy czym taki sam procent stanowily cielęta mocne fizycznie o zawartości tluszczu $80-100 \%$ (Ryc. 2). Mimo kontrowersyjnych danych o kondycji ofiar wilków wydaje się, że drapieżniki są lepszymi selekcjonerami niż myśliwi. 